\title{
Postharvest Quality of Beetroots Grown Under Different Irrigation Depths and Ascorbic Acid Doses
}

\author{
Anderson Carlos de Melo Gonçalves ${ }^{1}$, Toshik Iarley da Silva ${ }^{2}$, José Sebastião de Melo Filho ${ }^{3}$, \\ Joana Gomes de Moura ${ }^{3}$, Leonardo Vieira de Sousa ${ }^{3}$, Mário Leno Martins Veras ${ }^{2}$, Walter Esfrain Pereira ${ }^{3}$, \\ Álvaro Carlos Gonçalves Neto ${ }^{4}$, Thiago Jardelino Dias ${ }^{4} \&$ José de Anchieta Alves de Albuquerque ${ }^{1}$ \\ ${ }^{1}$ Center of Agrarian Sciences, Federal University of Roraima, Boa Vista, Roraima, Brazil \\ ${ }^{2}$ Center of Agrarian Sciences, Federal University of Viçosa, Viçosa, Minas Gerais, Brazil \\ ${ }^{3}$ Center of Agrarian Sciences, Federal University of Paraíba, Areia, Paraíba, Brazil \\ ${ }^{4}$ Center for Human, Social and Agrarian Sciences, Federal University of Paraíba, Bananeiras, Paraíba, Brazil \\ Correspondence: Anderson Carlos de Melo Gonçalves, Center of Agrarian Sciences, Federal University of \\ Roraima, Boa Vista, Roraima, Brazil. E-mail: anderson.agroufpb@yahoo.com
}

Received: May 23, 2019

doi:10.5539/jas.v11n16p180
Accepted: July 15, 2019 Online Published: September 30, 2019

URL: https://doi.org/10.5539/jas.v11n16p180

\begin{abstract}
Beetroot (Beta vulgaris L.) is a culture of great demand in Brazil due to its high nutritional value. However, water availability is a determining factor on its production. An alternative to reduce the damage caused by water stress is to apply organic solutes, such as ascorbic acid. The purpose hereof was to evaluate the postharvest quality of beetroots grown under different irrigation depths and ascorbic acid doses. The experiment was carried out in the Human, Social, and Agricultural Center's Postharvest Physiology and Technology Laboratory of the Federal University of Paraíba, Bananeiras, Paraíba, Brazil, in a completely randomized design with five doses of ascorbic acid $(0.00,0.29,1.00,1.71$, and $2.00 \mathrm{mM})$ and five irrigation depths $(40.0 \%, 51.6 \%, 80.0 \%, 108.4 \%$, and $120.0 \%$ of the evapotranspiration), combined according to each Box Central Compound experimental matrix, totaling nine treatments with five repetitions. The variables total soluble solids, electrical conductivity, hydrogenation potential, titratable acidity, total soluble solids and titratable acidity ratio, moisture, dry matter, and mineral matter were evaluated. The data were submitted for analysis of variance and polynomial regression. There was a significant interaction between the irrigation depths and the ascorbic acid doses in every variable, except for electrical conductivity and mineral matter. The postharvest characteristics of beetroots improved with applications of ascorbic acid doses in the thinner irrigation depths. The greatest dose of ascorbic acid (2 $\mathrm{mM})$ in the thinner irrigation depth $(40 \%)$ increases the postharvest quality of beet tuberous roots.
\end{abstract}

Keywords: Beta vulgaris L., water availability, organic solutes

\section{Introduction}

The horticultural or table beetroot (Beta vulgaris L.) is the most known beetroot variety in Brazil. It belongs to the Chenopodiaceae family and it originates from the Mediterranean coast (Costa et al., 2017). There is a culture of increasing consumption demand in Brazil, both in natural and industrialized states, due to its high concentrations of vitamins and nutrients (Paiva et al., 2017).

The olericulture is directly affected by the amount of water in the soil because it is determinant in vegetable physiology due to its participation in every phase of the plant. Both water deficit and excess limit the yield and final quality of the product in most cultures (Sousa et al., 2004; Santos et al., 2016). Irrigation is the cultural treatment that most increases the production of vegetables. Therefore, the proper management and adjustment of the irrigation depth in the cultures, especially during production, are necessary to guarantee greater quality harvests (Cavalcante et al., 2016).

Under water stress, organic solutes may be quantitatively and qualitatively changed, triggering relevant antioxidant effects in response to stress due to water availability restriction, generating tolerance in the plant (Silva et al., 2016). The application of organic solutes in plants under water stress can be an alternative to reduce the osmotic effect, guaranteeing the culture production (Lacerda et al., 2012). An osmolyte of great importance as antioxidant is the ascorbic acid (Terzi et al., 2015). 
The combined use of certain irrigation depths with an organic solute may contribute to the improvement of postharvest quality of tuberous beetroots. Due to the lack of scientific work on this subject, the purpose hereof was to evaluate the postharvest quality of beetroots (Beta vulgaris L.) grown under different irrigation depths in association with ascorbic acid doses.

\section{Method}

\subsection{Location of Study Area}

The experiment has been carried out from May to August 2017, in a protected environment at the Agricultural Sciences Center of the Federal University of Paraíba, in the city of Areia, Paraíba, Brazil.

\subsection{Research Design}

The experimental design was completely randomized with five doses of ascorbic acid $(0.00,0.29,1.00,1.71$, and $2.00 \mathrm{mM}$ ) and five irrigation depths $(40.0,51.6,80.0,108.4$, and $120.0 \%$ of evapotranspiration), combined according to the Box Central Compound experimental matrix, totaling nine treatments: T1, 1.71 and 108.4; T2, 1.71 and 51.6; T3, 0.29 and 108.4; T4, 0.29 and 51.6; T5, 2.0 and 80; T6, 0.0 and 80; T7, 1.0 and 120; T8, 1.0 and 40 ; and $\mathrm{T} 9,1.0 \mathrm{mM}$ and $80 \%$ of the evapotranspiration (ETc) with five repetitions. The treatments began 21 days after germination (DAG) until the end of the culture cycle.

Maravilha Top Tall Early Wonder cultivar seeds were employed (Feltrin ${ }^{\circledR}$ seeds). Five seeds per vase were used, which after germination stabilization (5 days after the sowing) and 15 days later, were thinned, remaining only the most vigorous one. The vases employed had a volume capacity of about $5 \mathrm{dm} 3$ with holes on the bottom to allow a better root aeration and to facilitate the water excess percolation, avoiding the exit of soil from the vases. The soil employed was classified as endic Eutrophic Haplic Planosol (EMBRAPA, 2014). Its chemical and physical characteristics (Table 1) were analyzed according to the methodologies of EMBRAPA (2009) and EMBRAPA (2014), respectively.

Table 1. Chemical and physical characteristics of the soil employed in the experiment

\begin{tabular}{|c|c|c|c|c|c|c|c|c|c|c|c|c|}
\hline \multicolumn{13}{|c|}{ Chemical analysis of soil } \\
\hline pH & $\mathbf{P}$ & $\mathbf{K}^{+}$ & $\mathrm{Na}^{+}$ & $\mathbf{H}+\mathbf{A l}$ & $\mathbf{A l}^{+3}$ & $\mathbf{C a}^{+2}$ & Mg & SEB & CEC & $\mathbf{V}$ & $\mathbf{m}$ & O.M. \\
\hline & \multicolumn{2}{|c|}{---- $\mathrm{mg} \mathrm{dm}^{-3}$---- } & \multicolumn{7}{|c|}{ - } & \multicolumn{2}{|c|}{------- \% ------. } & $\mathrm{g} \mathrm{Kg}^{-1}$ \\
\hline 6.26 & 11.35 & 40 & 0.22 & 1.82 & 0.00 & 3.00 & 1.90 & 5.22 & 7.03 & 74.34 & 0.00 & 17.53 \\
\hline \multicolumn{13}{|c|}{ Physical soil analysis } \\
\hline SD & DP & TP & Fc & PWP & Sand & Silt & Clay & \multicolumn{5}{|c|}{ Textural classification } \\
\hline \multicolumn{2}{|c|}{----- $\mathrm{g} \mathrm{cm}^{-3}$----- } & $\mathrm{m}^{3} \mathrm{~m}^{-3}$ & $---\cdot$ & ------- & $-\mathrm{g} \mathrm{kg}^{-1}$ & ----- & ----- & \multirow{2}{*}{\multicolumn{2}{|c|}{$\begin{array}{l}\text {---- Embrapa ---- } \\
\text { Average }\end{array}$}} & \multirow{2}{*}{\multicolumn{3}{|c|}{$\begin{array}{l}\text {---- Atterberg ---- } \\
\text { Sandy loam }\end{array}$}} \\
\hline 1.38 & 2.67 & 0.48 & 78 & 43 & 756.9 & 59.1 & 184.0 & & & & & \\
\hline
\end{tabular}

Note. $\mathrm{pH}=$ water: $1: 2.5 ; \mathrm{P}, \mathrm{K}, \mathrm{Na}=$ Mehlich Extractor; $\mathrm{H}+\mathrm{Al}=$ Calcium Acetate Extractor $0.5 \mathrm{M}, \mathrm{pH} 7.0 ; \mathrm{Al}$, $\mathrm{Ca}, \mathrm{Mg}=1 \mathrm{M} \mathrm{kCl}$ Extractor; $\mathrm{SEB}=$ Sum of Exchangeable Bases; $\mathrm{CEC}=$ Cation Exchange Capacity; $\mathrm{V}=$ Basis Saturation; $\mathrm{m}=$ Saturation by $\mathrm{Al}^{3+}$; O.M. = Organic Matter; $\mathrm{SD}=$ Soil Density; $\mathrm{DP}=$ Density of Particle; $\mathrm{TP}=$ Total Porosity; Fc = Field Capacity; PWP = Permanent Withering Point.

The sowing fertilization and cover were made at doses of 40, 180, and $90 \mathrm{~kg} \mathrm{ha}^{-1}$ of $\mathrm{N}, \mathrm{P}_{2} \mathrm{O}_{5}$ e $\mathrm{K}_{2} \mathrm{O}$, respectively, with urea, simple superphosphate and potassium chloride, according to chemical soil analysis and fertilization recommendation for the State of Pernambuco (IPA, 2008). Phytosanitary controls of pests and weeds were manually performed during the experiment. No diseases were observed during the beetroot culture cycle.

For the irrigation depth management, weight lysimeters of $100 \%$ evapotranspiration reposition were used as reference. During the first sowing day, the irrigation depth was calculated according to Mantovani et al. (2009), considering a root system depth of $15 \mathrm{~cm}$ (soil depth in the vase), increasing the moisture of the soil to field capacity. From the second sowing day onwards, the irrigation depth was determined according to the evapotranspiration patch registered by the weight lysimeters, keeping the soil's moisture between the field capacity and the critical moisture levels, established by $50 \%$ of available water, and the values were registered during the entire culture cycle (Figure 1). The total irrigation required was calculated according to Bernardo et al (2008), considering a 100\% level of irrigation application efficiency.

The harvest has been determined by the plants of the weight lysimeters, considering the diameter of the tuberous root around $5 \mathrm{~cm}$ (Tivelli et al., 2011) after 82 of germination. 


\subsection{Data Collection}

After the harvest, the beetroots were conducted for the PostHarvest Physiology and Technology Laboratory of the Human, Social, and Agricultural Center's of the Federal University of Paraíba, Bananeiras, Paraíba, Brazil, for analysis of total soluble solids, electrical conductivity, potential of hydrogen $(\mathrm{pH})$, titratable acidity $(\%$ citric acid), total soluble solid and titratable acidity ratio, moisture, dry matter, and mineral matter (ash), determined according to the manual of Instituto Adolfo Lutz (2008).

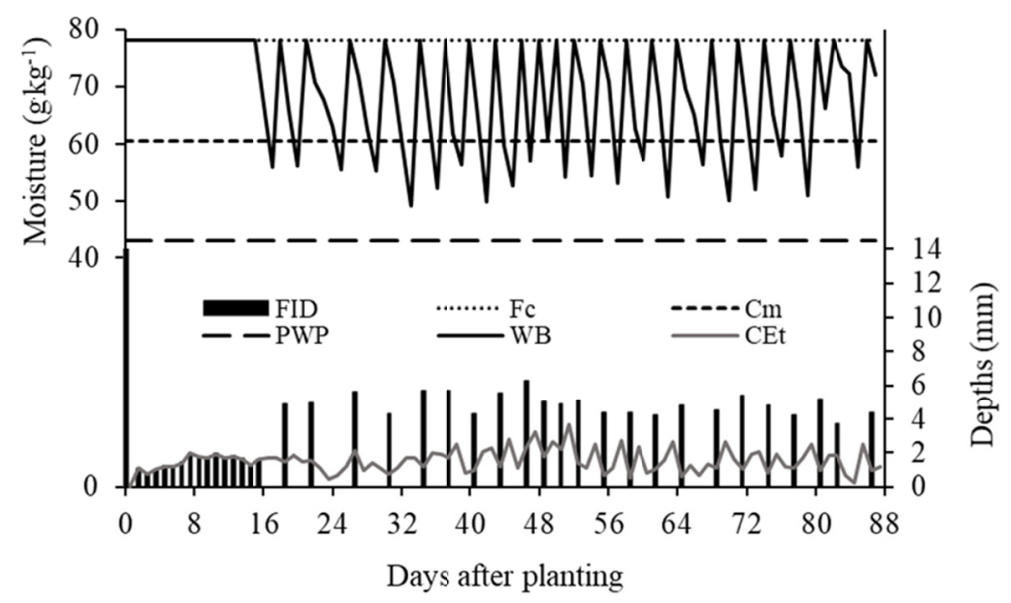

Figure 1. Water data of the soil in the weight lysimeters of $100 \%$ evapotranspiration reposition for the days after sowing in Beta vulgaris L. Water balance (WB), field capacity $(\mathrm{Fc})$, critical moisture $(\mathrm{Cm})$, permanent withering point (PWP) in $\mathrm{g} \mathrm{kg}^{-1}$, and frequency and irrigation depth (FID) and culture evapotranspiration (CEt), in $\mathrm{mm}$

\subsection{Statistics and Data Analysis}

The resulting data from the evaluated variables were submitted to analysis of variance and polynomial regression, using the SAS ${ }^{\circledR}$ University statistical package (CODY, 2015).

\section{Results and Disccussion}

The interactions between the irrigation depths with the ascorbic acid (AA) doses were significant for the postharvest variables of the tuberous beetroots (Beta vulgaris L.), except for mineral matter (ash) and electrical conductivity.

As regards total soluble solids (Figure 2A), there was a linear increase with the increase of AA doses in the thinner irrigation depth, as in the deeper irrigation depth $(120 \%)$, there was practically no variation. Possibly, the greatest water solubility diluted the total soluble solids and consequently decreased their levels in the pulp, similar to that found by Dolker et al. (2017), and by Silva et al. (2013), which worked with citrus and graviola, respectively, submitted to water deficit verified higher values of total soluble solids under conditions of soil water deficit in the root zone of plants.

The extreme AA values under water stress resulted in greater potential of hydrogen ( $\mathrm{pH}$ ) values (Figure 2B), which is possibly justified by the increase of antioxidants, developed as a consequence of water stress, which donate hydrogen ions to free radicals during the oxidation caused by water restriction in the pulp of beet tuberous roots (Brewer, 2011), as verified by Murshed et al. (2013), which investigated the effect of water deficit on some oxidative parameters and antioxidant systems on tomato Micro-Tom fruits at different stages of development, the authors verified that the concentrations of ascorbate (AsA) and dehydroascorbate (DHA) are modified with stress water.

The lesser total titratable acidity values (\% citric acid) (Figure 2C) were obtained as the water availability and AA doses increased. The AA probably did not help to accumulate citric acid; only water stress did. Such response may be related to the dilution effect of organic acids by the water amount increase in the culture production (Soares et al., 2013; González-Chavira et al., 2018) and by the accumulation of different solutes under water stress (Wu et al., 2016).

Due to the inverse relation between the results of total soluble solids and titratable acidity, it has been noticed that greater irrigation depths resulted in positive increases in the total soluble solids and titratable acidity ratio 
(Figure 2D), with no visible interference of the AA doses. However, it has noticed that in the thinner irrigation depths, there was an AA synergistic effect in the increase of TSS/TA, justified by the accumulation of several types of organic solutes synthesized by the water restriction (Silva et al., 2014; Zouaoui et al., 2019).
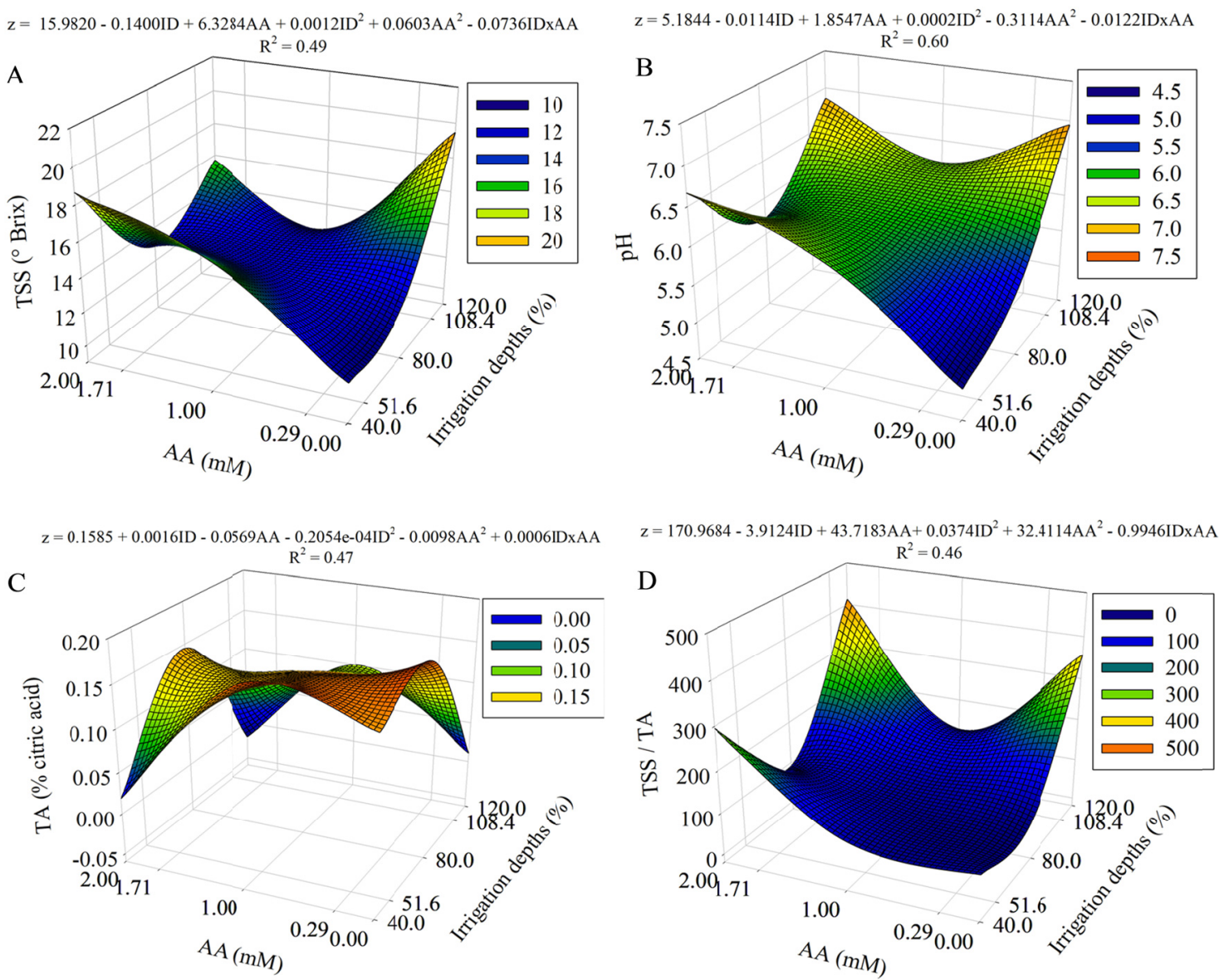

Figure 2. Total soluble solids (TSS) (A), potential of hydrogen (pH) (B), titratable acidity (TA) (C), total soluble solids and titratable acidity ratio (TSS/TA) (D) of tuberous roots of beets grown according to the irrigation depths (\%) and ascorbic acid (AA) applications

The greater AA doses in the deeper irrigation depths resulted in greater moisture values in the pulp (Figure 3A). Possibly under water deficit, the AA application did not favor the water retention in the root cells. However, the plant probably kept its turgor pressure during water stress in the leaves, protecting the cell compartments from possible damage caused by dehydration (Waraich et al., 2011) because AA plays an important role in the elimination of oxygen reactive species produced under water restriction conditions (Hameed et al., 2015).

The behavior of the dry matter mass of the pulp (Figure 3B) was inverse to that observed for the moisture of pulp, that is, the AA applications favored the increase of dry mass under severe water restriction. However, its action has reduced as the water availability increased, becoming even harmful in deeper irrigation depths, probably due to pro-oxidative effect of AA resulting from the generation of oxygen reactive species when the is no need of osmotic adjustment (Hussain et al., 2017).

The electrical conductivity of the pulp of the beet tuberous root was not affected by the two evaluated factors, with an average value of $1731.04 \mu \mathrm{Sm} \mathrm{cm}{ }^{-1}$. The use of uniform electrical conductivity factors (AA and irrigation depths) probably did not interfere with the electrical conductivity of the pulp. Medeiros et al. (2014) verified that the electrical conductivity of yellow passion fruit pulp increased with the increase of electrical conductivity of the irrigation water.

Neither AA doses nor irrigation depths affected mineral matter (ash), reaching a mean of $1.49 \%$, which is probably justified by the fact that the evaluated factors did not contribute to increase the mineral concentration in 
the tuberous roots, because they have only organic chemical elements in their constitution (Farahat et al., 2018). The values found were higher than those found by Tivelli et al. (2011), which obtained the value of $1.1 \%$.
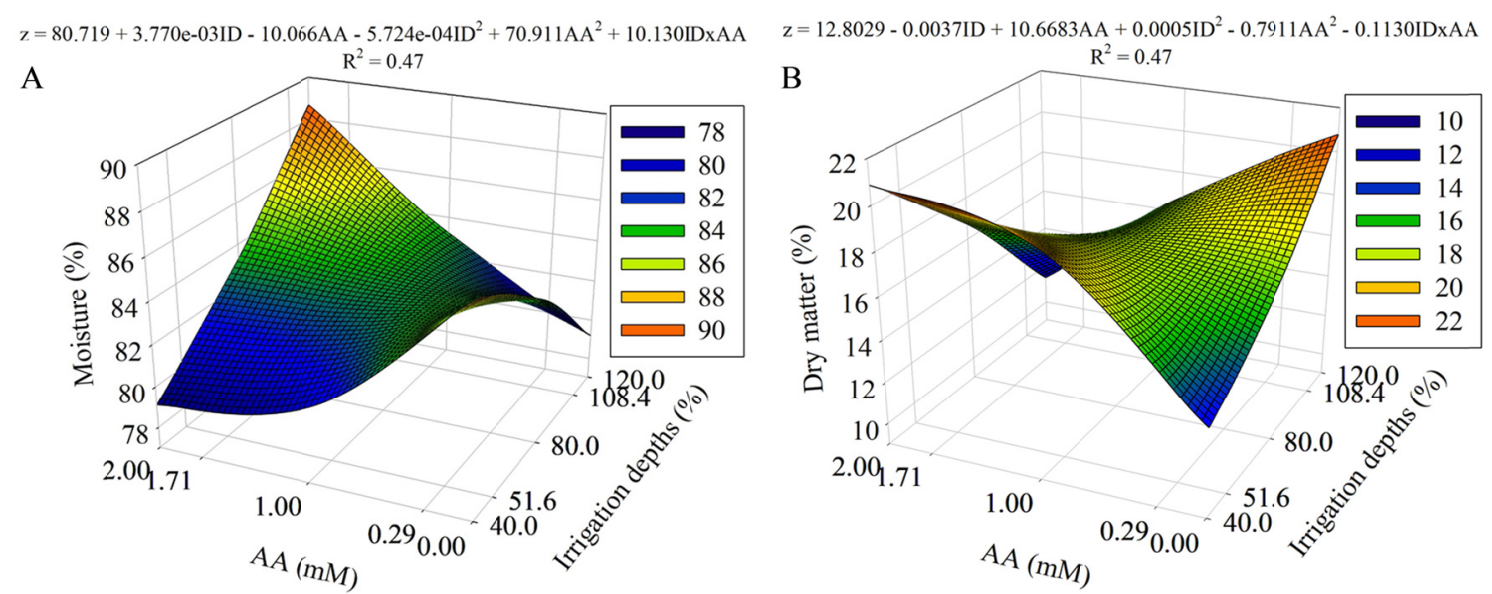

Figure 3. Moisture (A) and dry matter mass (B) of beet tuberous roots grown according to the irrigation depths (\%) and ascorbic acid (AA) applications

\section{Conclusions}

Total soluble solids, potential of hydrogen, total soluble solids and titratable acidity ratio, and dry mass of pulp of beet (Beta vulgaris L.) tuberous root increase with the ascorbic acid doses and with the thinner irrigation depth, which decrease the titrable acidity and moisture. Neither irrigation depth nor application of ascorbic acid affected the electrical conductivity of pulp and the mineral contents (ashes). The moisture of the pulp decreased and the dry mass increased with the greatest dose of ascorbic acid in the thinner irrigation depth. The greatest dose of ascorbic acid $(2 \mathrm{mM})$ in the thinner irrigation depth $(40 \%)$ increases the postharvest quality of beet tuberous roots.

\section{References}

Bernardo, S., Soares, A., \& Mantovani, E. C. (2008). Manual de irrigação (p. 625). Viçosa, MG: UFV.

Brewer M. S. (2011). Natural antioxidants: Sources, compounds, mechanisms of action, and potential applications. Comprehensive Reviews in Food Science and Food Safety, 10, 221-247. https://doi.org/ 10.1111/j.1541-4337.2011.00156.x

Cavalcante, L. F., Rocha, L. F., Silva, R. A. R., Souto, A. G. L., Nunes, J. C., \& Cavalcante, Í. H. L. (2016). Produção e qualidade da graviola sob irrigação e cobertura do solo com resíduo de sisal. Magistra, 28(1), 91-101.

Cody, R. (2015). An introduction to SAS. Cary: SAS Institute.

Costa, F. A., Nascimento, W. M., \& Silva, P. P. (2017). Table beet floral induction by artificial vernalization of roots under Brasília conditions. Savannah Journal of Research and Development, 1(1), $28-33$. https://doi.org/10.26512/savannahjournal.v1i1.7365

Dolker, D., Bakshi, P., Dorjey, S., Choudhary, P., Kour, K., \& Singh, M. (2017). Effect of Deficit Irrigation Scheduling on Yield and Quality of Kinnow Mandarin Fruits. International Journal of Current Microbiology and Applied Sciences, 6(7), 261-269. https://doi.org/10.20546/ijcmas.2017.607.031

EMBRAPA (Empresa Brasileira de Pesquisa Agropecuária). (2009). Manual de análises químicas de solos, plantas e fertilizantes. Brasília, DF: Embrapa Solos.

EMBRAPA (Empresa Brasileira de Pesquisa Agropecuária). (2014). Sistema Brasileiro de Classificação de Solo. Brasília, DF: Embrapa Solos.

Farahat, M. M., Aziz, N. G. A., Hashish, K. I., \& Mazhar, A. A. M. (2018). Effect of ascorbic acid on growth and chemical constituents of Monstera delicious under lead pollutant conditions. Agricultural Engineering International, 19(5), 239-244. 
González-Chavira, M. M., Herrera-Hernández, M. G., Guzmán-Maldonado, H., \& Pons-Hernández, J. L. (2018). Controlled water deficit as abiotic stress factor for enhancing the phytochemical content and adding-value of crops. Scientia Horticulturae, 234, 354-360. https://doi.org/10.1016/j.scienta.2018.02.049

Hameed, A., Gulzar, S., Aziz, I., Hussain, T., Gul, B., \& Khan, M. A. (2015). Effects of salinity and ascorbic acid on growth, water status and antioxidant system in a perennial halophyte. AoB Plants, 7, 1-37, https://doi.org/10.1093/aobpla/plv004

Hussain, I., Siddique, A., Ashraf, M. A., Rasheed, R., Ibrahim, M., Iqbal, M., Akbar, S., \& Imran, M. (2017). Does exogenous application of ascorbic acid modulate growth, photosynthetic pigments and oxidative defense in okra (Abelmoschus esculentus (L.) Moench) under lead stress? Acta Physiologiae Plantarum, 39(6), 144-157. https://doi.org/10.1007/s11738-017-2439-0

Instituto Adolfo Lutz. (2008). Métodos físico-químicos para análises de alimentos. São Paulo: Instituto Adolfo Lutz.

IPA (Instituto Agronômico de Pernambuco). (2008). Recomendação de adubação para o Estado de Pernambuco: 2 aproximação. Recife: Instituto Agronômico de Pernambuco, IPA.

Lacerda, F. H. D., Pereira, F. H. F., Neves, D. S., Borges, F. Q. C., \& Campos Júnior, J. E. (2012). Aplicação exógena de prolina na redução do estresse salino em meloeiro. Revista Verde de Agroecologia e Desenvolvimento Sustentável, 7(3), 218-227.

Mantovani, E. C., Bernardo, S., \& Palaretti, L. F. (2009). Irrigação: princípios e métodos. Viçosa: UFV. https://doi.org/10.15809/irriga.2009v14n4p458-469

Medeiros, W. J. F., Oliveira, F. Í. F., Cavalcante, L. F., Costa, L. C., Rocha, R. H. C., \& Silva, A. R. (2014). Qualidade química em frutos de maracujazeiro amarelo cultivado em solo com biofertilizantes bovino. Magistra, 26(2), 156-168.

Murshed, R., Lopez-Lauri, F., \& Sallanon, H. (2013). Effect of water stress on antioxidant systems and oxidative parameters in fruits of tomato (Solanum lycopersicon L, cv. Micro-tom). Physiology and Molecular Biology of Plants, 19(3), 363-378. https://doi.org/10.1007/s12298-013-0173-7

Paiva, P. V. V., Valnir Júnior, M., Lima, L. S. S., Rocha, J. P. A., Demontiezo, L., Levy, F., \& Aragão, M. F. (2017). Avaliação de crescimento de cultivares de beterraba de mesa sob diferentes lâminas de irrigação. Revista Brasileira de Agricultura Irrigada, 11(2), 1271-1277. https://doi.org/10.7127/rbai.v11n200597

Santos, D. P. D., Santos, C. S. D., Silva, P. F. D., Pinheiro, M. P. M. A., \& Santos, J. C. (2016). Growth and biomass beet under irrigation supplementary with water different concentrations saline. Revista Ceres, 63(4), 509-516. https://doi.org/10.1590/0034-737X201663040011

Silva, A. R., Bezerra, F. M., Lacerda, C. F. D., Miranda, R. D. S., Marques, E. C., \& Gomes-Filho, E. (2016). Organic solutes in coconut palm seedlings under water and salt stresses. Revista Brasileira de Engenharia Agricola e Ambiental, 20(11), 1002-1007. https://doi.org/10.1590/1807-1929

Silva, R. A., Nunes, J. C., Lima Neto, A. J., Cavalcante, L. F., Silva, M. R., \& Rodrigues, R. M. (2013). Lâminas de irrigação e cobertura do solo na produção e qualidade de frutos da gravioleira. Revista Brasileira de Ciencias Agrarias, 8(3), 441-447. https://doi.org/10.5039/agraria.v8i3a2669

Silva, R. F., Eitelwein, M. T., Cherubin, M. R., Fabbris, C., Weirich, S., \& Pinheiro, R. R. (2014). Produção de mudas de Eucalyptus grandis em substratos orgânicos alternativos. Ciência Florestal, 24(3), 609-619. https://doi.org/10.5902/1980509815745

Soares, L. A., Brito, M. E. B., Araújo, T. T., Sá, F. V. S., Silva, E. C. B., \& Oliveira, E. S. (2013). Morfofisiologia e qualidade pós-colheita do tomateiro sob estresse hídrico nas fases fenológicas. Revista Verde de Agroecologia e Desenvolvimento Sustentável, 8(1), 239-246.

Sousa, G. G., Viana, T. V. A., Dias, C. N., Silva, G. L., \& Azevedo, B. M. (2014). Lâminas de irrigação para cultura do gergelim com biofertilizante bovino. Magistra, 26(3), 343-352.

Terzi, R., Kalaycioglu, E., Demiralay, M., Saglam, A., \& Kadioglu, A. (2015). Exogenous ascorbic acid mitigates accumulation of abscisic acid, proline and polyamine under osmotic stress in maize leaves. Acta Physiologiae Plantarum, 37(3), 43-52. https://doi.org/10.1007/s11738-015-1792-0

Tivelli, S. W., Factor, T. L., Teramoto, J. R. S., Fabri, E. G., Moraes, A. R. A., Trani, P. E., \& May, A. (2011). Beterraba do plantio à comercialização (p. 45). Campinas, SP: IAC. 
Waraich, E. A., Ahmad, R., Ashraf, M. Y., \& Ahmad, S. M. (2011). Improving agricultural water use efficiency by nutrient management in crop plants. Acta Agriculturae Scandinavica, Section B-Soil \& Plant Science, 61(4), 291-304. https://doi.org/10.1080/09064710.2010.491954

Wu, G. Q., Feng, R. J., \& Shui, Q. Z. (2016). Effect of osmotic stress on growth and osmolytes accumulation in sugar beet (Beta vulgaris L.) plants. Plant Soil Environ, 62(4), 189-194. https://doi.org/10.17221/ 101/2016-PSE

Zhang, H., Xiong, Y., Huang, G., Xu, X., \& Huang, Q. (2016). Effects of water stress on processing tomatoes yield, quality and water use efficiency with plastic mulched drip irrigation in sandy soil of the Hetao Irrigation District. Agricultural Water Management, 179, 205-214. https://doi.org/10.1016/j.agwat.2016. 07.022

Zouaoui, R., Ammari, Y., Abassi, M., Ahmed, H. B., Smaoui, A., \& Hilali, K. (2019). Physiological and biochemical responses of Rhus tripartita (ucria) grande under water stress. Pakistan Journal of Botany, 51(4), 1215-1221. https://doi.org/10.30848/PJB2019-4(22)

\section{Copyrights}

Copyright for this article is retained by the author(s), with first publication rights granted to the journal.

This is an open-access article distributed under the terms and conditions of the Creative Commons Attribution license (http://creativecommons.org/licenses/by/4.0/). 